\title{
Stress intensity of a nursing students regarding to biosocial and academic characteristics - A cross-sectional study
}

\author{
Ana Lucia Siqueira Costa ${ }^{1}$, Laura de Azevedo Guido ${ }^{2}$, Rodrigo Marques da Silva ${ }^{3}$, Luis Felipe Dias \\ Lopes $^{4}$, Fernanda Carneiro Mussi ${ }^{5}$ \\ 1. School of Nursing, University of São Paulo, São Paulo, Brazil. 2. Nursing Department, Federal University of Santa Maria, \\ Santa Maria, Brazil. 3. Nursing Post-Graduation Program, Federal University of Santa Maria, Santa Maria, Brazil. 4. \\ Administrative Sciences Department, Federal University of Santa Maria, Santa Maria, Brazil. 5. Nursing Department, \\ Federal University of Bahia, Salvador, Brazil. \\ Correspondence: Ana LúciaSiqueira Costa. Address: School of Nursing, University of São Paulo, 334 Oscar Caravelas St., \\ 52. São Paulo. Brazil. Email: ananascosta@usp.br
}

Received: May 23, 2013

DOI : $10.5430 /$ jnep.v4n2p29
Accepted: July 22, 2013

Online Published: September 16, 2013

\section{Abstract}

Background/Objective: Different studies, in national and international context, have linked stress to the academic activities of nursing students. However, investigations relating environmental characteristics in this context were limited. So, we compared stress intensity regarding to biosocial and academic characteristics of nursing students.

Method: It is a quantitative, analytical and cross-sectional study, conducted among 160 students of a Nursing Undergraduate course from São Paulo. A Form to Biosocial and Academic Characterization and the instrument for the Assessment of Stress among Nursing Students (ASNS) were applied. Data analysis was performed using the MannWhitney test to compare stress intensity by group of students (academic and biosocial data) in each ASNS domain. The significance level used was $5 \%$.

Results: We verified that Time Management represented higher stress to students who use the subway, are not family dependent to maintenance, have work activity, and does not perform sports, neither leisure activities. The Environment represented higher stress to students who use public transport (train and subway) and does not practice leisure activities. Those who do not perform this activity showed higher stress in Professional Education domain.

Conclusion: The biosocial and academic context observed favors stress occurrence in nursing students. Therefore, we suggest performing studies that help students to choose more effective strategies to deal with stressors in order to live their training period with more satisfaction and less suffering.

\section{Key words}

Nursing, Psychological stress, Analytic epidemiology, Biosocial and academic characteristics

\section{Introduction}

Different researches have been developed in order to analyze stress among students from different training areas. Nursing deserves a special attention because it is recognized worldwide as a stressful profession. In this same trajectory, resear- 
chers recognize that stress is present since training period, when student is faced to challenging situations that may interfere in his teaching-learning process ${ }^{[1-6]}$.

In this context, besides the academic activities, students develop some assistance and managerial nurses' functions in training process and, thus, they experience the health services reality. So they perform different practices and interventions to patient care, although not legally included in the institution staff team, with benefits that protect them in practice. Besides, these students are in learning phase, imbued with insecurity and fear feelings and they need to meet the academic requirements pertinent to their training phase ${ }^{[7]}$.

In this sense, it is evidenced that stress among nursing students occurs in different situations, such as: school activities experienced in first 12 months of initial entry into college; traumatic experiences of death; responsibility perception in offer care to ill people when the student still is newly entering; requirements regarding to performance and interpersonal relationships; feeling of unpreparedness to perform needed functions in stages and practical classes; and adaptation to academic demands ${ }^{[5,8-11]}$.

In this context, some situations can be evaluated as stressful and lead nursing students to stress. Thus, researches have analyzed stress and its linkage with academic or assistance activities, well as their consequences to physical and mental health of students. Exemplifying, research with nursing students of first year showed that clinical practice represents more stress to students than theoretical classes due to knowledge and skills limitation and to necessity of establishing professsional relationships with nursing team in first practice classes ${ }^{[10]}$. Moreover, as stress repercussion on students health, investigations highlight occurrence of depression, Burnout Syndrome and anxiety among these individuals ${ }^{[5,12]}$, relationship already observed with statistical significance in different studies ${ }^{[12-14]}$. Moderate/low levels of depression and anxiety were found, respectively, in $27.1 \%$ and $47.1 \%$ of Turkish university students ${ }^{[5]}$. In investigation with 743 medical students, the prevalence of stress, anxiety and depression of moderate/severe level were $3.6 \%, 54.5 \%$ and $1.9 \%$, respecttively ${ }^{[15]}$. In the academic context, researchers found $48.6 \%$ of 4287 medical students from Washington ${ }^{[16]}$ and $45 \%$ of 545 students from Minnesota ${ }^{[17]}$ with the Burnout Syndrome. When Brazilian students of different undergraduate courses were analyzed, $17 \%$ of 235 dental students ${ }^{[18]}$ and $10.3 \%$ of 369 medical students showed Burnout ${ }^{[19]}$.

When the relationship between stress and depression was analyzed in a survey with 88 nursing students of São Paulo ${ }^{[12]}$, the data showed a relation between stress and presence of depression signs, especially of severe depression. Concerning to stress and Burnout Syndrome, a significant correlation between these phenomena was found in an investigation with 75 nursing students from EUA ${ }^{[20]}$.

Based on researches described, we can observe that nursing training can lead students to stress and its occurrence presents different outcomes for their health. However, psychosocial context also is important in students' education process. In a literature review ${ }^{[21]}$, it was found that few studies consider the biosocial and academic conditions as stressors for nursing students. Among them, we highlight collective transport means used in big cities and, consequently, time that students spend to arrive in institution and internship places; economic conditions necessary for their maintenance in an undergraduate course for years in full time; overload of academic activities; and the way which students manage their time to meet the academic demands (many times, labor ones) and still maintain healthy habits, such as sports and leisure practices. Thereby, the knowledge about biosocial and academic situation of nursing students is important to provide the development of policies and to relieve the impact of these situations on students ${ }^{[21]}$.

Having in view the different studies about stress already published, we stand out that stress concept adopted in this research was that proposed by Lazarus and Folkman according to the Transactional Model of stress. In this model, the relationship between individuals and their environment are considered, as well as the attribution of meaning to events by individuals ${ }^{[22]}$. In the events evaluation process, stress manifestations can arise in accordance with individual resources available to lead with them. As the physiological differences affect the individual's response to the event, becomes difficult predict a response based on the situation involved ${ }^{[23]}$. 
In this sense, there are gaps in knowledge production about comparison of stress intensity and of stress factors among nursing students regarding to biosocial and academic characteristics. Thus, as stress interferes in teaching-learning quality of students and its occurrence may be related to biosocial and academic characteristics, we question: Is there a difference between stress intensity regarding to academic and biosocial characteristics presented by nursing students?

Based on this question, the aim of this study was to compare stress intensity regarding to biosocial and academic characteristics of nursing students.

\section{Materials and methods}

Quantitative, analytical and cross-sectional study, conducted among 160 students of a nursing undergraduate course located in São Paulo.

\subsection{Sample}

The study population was composed by students of nursing undergraduate course and sample composition followed the proportionality criterion, considering relationship between number of students in each semester and the total of undergraduates enrolled in the year. The instruments for data collection were applied in 160 (50.63\%) students (total of $316)$, distributed among the four years of undergraduate degree. Of these, 44 (51.76\%) students were enrolled in first year (total of 85), 42 (53.84\%), in second (total of 78), 36 (48\%) in third (total of 75) and 38 (48.72\%) in fourth year (total of 78).

\subsection{Measurement instrument}

The Form to Biosocial and Academic Characterization was composed by following variables: age, gender, school semester, city of residence, transport mean, family constitution, family economic status, activity of leisure, practice of sports, work activity, hours dedicated to studies and existence of some financial support source.

The instrument for the Assessment of Stress among Nursing Students (ASNS) ${ }^{[24]}$ was developed and validated for Brazilian reality in 2009 following criteria of good methodological and technical reliability and acceptability. Thus, the ASNS allows evaluating the stress factors (domains) intensity in nursing students. This instrument is made up of 30 items presented in Likert scale with four points, as follows: zero (0), applied when the student did not experience stress at the situation depicted in the item; one (1) when stress level is regarded as low by the student in the presented situation; two (2), when the situation represents a moderate stress level; and three (3), when the student perceives the situation as a highly stressful one. These items are allocated into six domains that represent stressors of the academic context, to be: Performance of Practical Activities (PPA), Environment (ENV), Professional Communication (PC), Time Management (TM), Professional Education (PE) and Theoretical Activities (TA) ${ }^{[24]}$.

\subsection{Procedure}

With previous scheduling, we attended the classroom or training / practical classes fields and, in interval time, we requested that students participate in the study. Those who agreed to participated received the Free and Informed Consent Term and, after signing it, the Form to Biosocial and Academic Characterization and the instrument for the Assessment of Stress among Nursing Students. Data collection extended over three months until the number of students required for the study was reached.

\subsection{Data analyses}

The collected data were organized into a database in Microsoft Excel (version 2003) and analyzed through the Statistical Analysis System (SAS) software, version 9.

To check differences between stress intensity of students in each domain regarding to biosocial and academic variables, Normality Test (Shapiro-Wilk) was applied. However, due to non-normality of data, we applied Mann-Whitney and 
Kruskal-Wallis non-parametric tests. Kruskal-Wallis test was applied to analyze gender and school semester and Mann-Whitney was used to analyze all other variables.

The Instrument to Assessing Stress in Nursing Students reliability was analyzed using the Cronbach Alpha coefficient.

\section{Ethical considerations}

The current research is part of the project named "Development and validation of an instrument to assess stress in nursing students” which received support from the São Paulo Research Foundation - FAPESP. This project was submitted to the Research Ethics Committee at Nursing School of this study and it obtained approval under process n 480/2005. All participants were informed about study goal and anonymity and confidentiality of their responses. In case of acceptance, they signed the Free and Informed Consent Term.

\section{Results}

In the internal consistency analysis of 30 items that comprise the ASNS, we obtained a Cronbach's alpha of 0.894 . The Alpha values by each instrument domain were: 0.801 for "Performance of Practical Activities", 0.768 for "Professional Communication”, 0.717 for “Time Management”, 0.866 for "Environment”; 0.772 for "Professional Education” and 0.720 for "Theoretical Activities". These values attest satisfactory reliability to instrument used for the population of this study ${ }^{[25]}$.

About differences between students stress intensity regarding to academic and biosocial variables, only the significant results from at least one group of variables are presented. In this sense, in Table 1, we show the comparison between stress intensity in general and per domain regarding to locomotion means.

Table 1. Comparison Between Stress Intensity Regarding to Locomotion Means. São Paulo, 2013

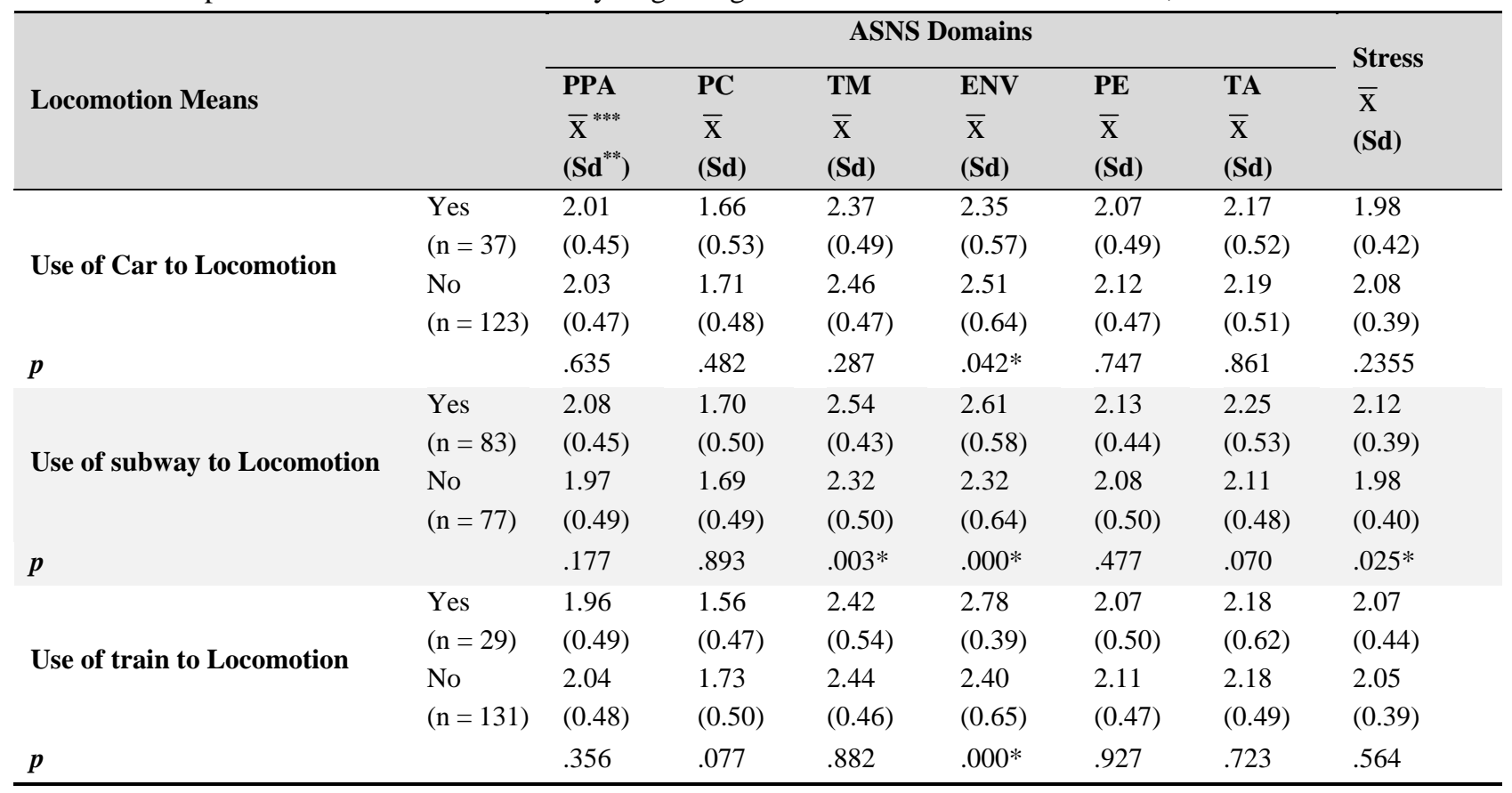

*Statistically significant difference $(p<.05)$ (Mann-Whitney Test)

**Sd = Standard Deviation

$* * * \overline{\mathrm{X}}=$ Mean 
In Table 2, we present results of the comparison between stress intensity in general and per domain of the ASNS regarding to practice of leisure and sports.

Table 2. Comparison between Stress Intensity Regarding to Leisure and Sports Practice. São Paulo. 2013.

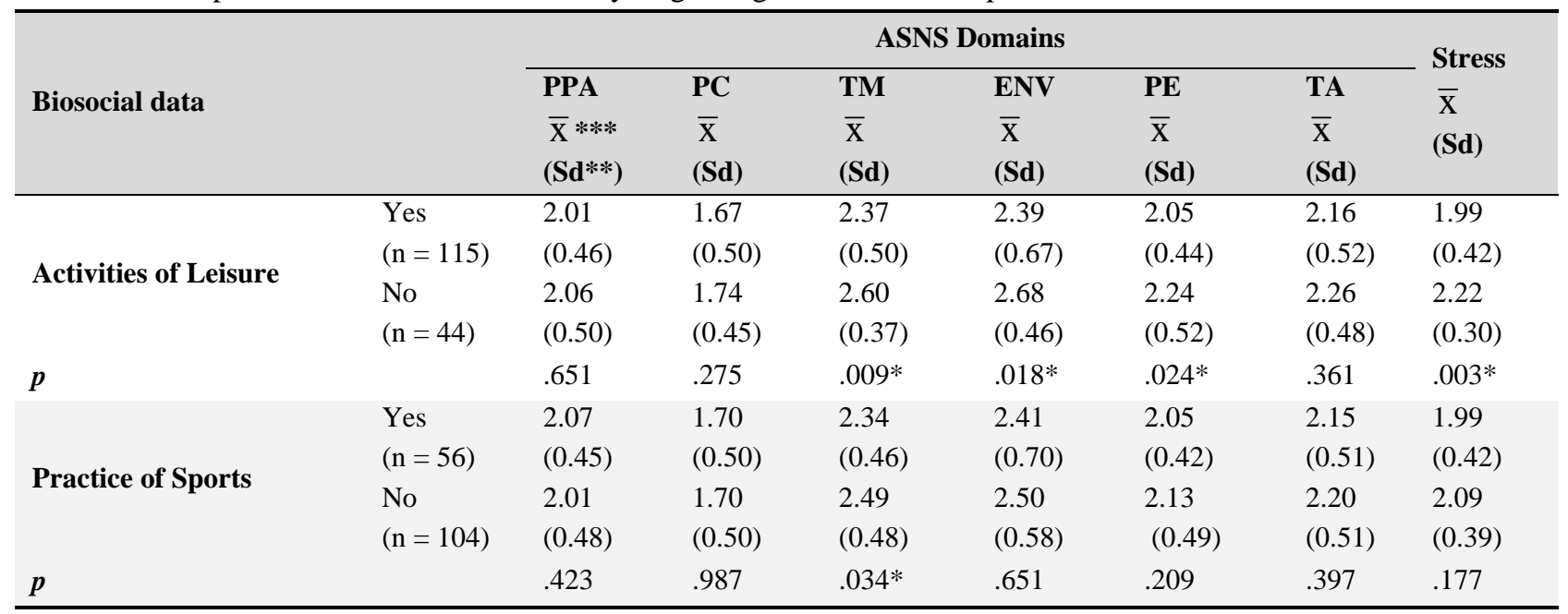

*Statistically significant difference $(p<.05)$ (Mann-Whitney Test)

$* *$ Sd $=$ Standard Deviation

$* * * \overline{\mathrm{X}}=$ Mean

Data relating to comparison between stress intensity presented by students in ASNS domains regarding to Dependence of Family and Work Activity variables are presented in Table 3.

Table 3. Comparison between Stress Intensity Regarding to Dependence of Family and Work Activity. São Paulo. 2013

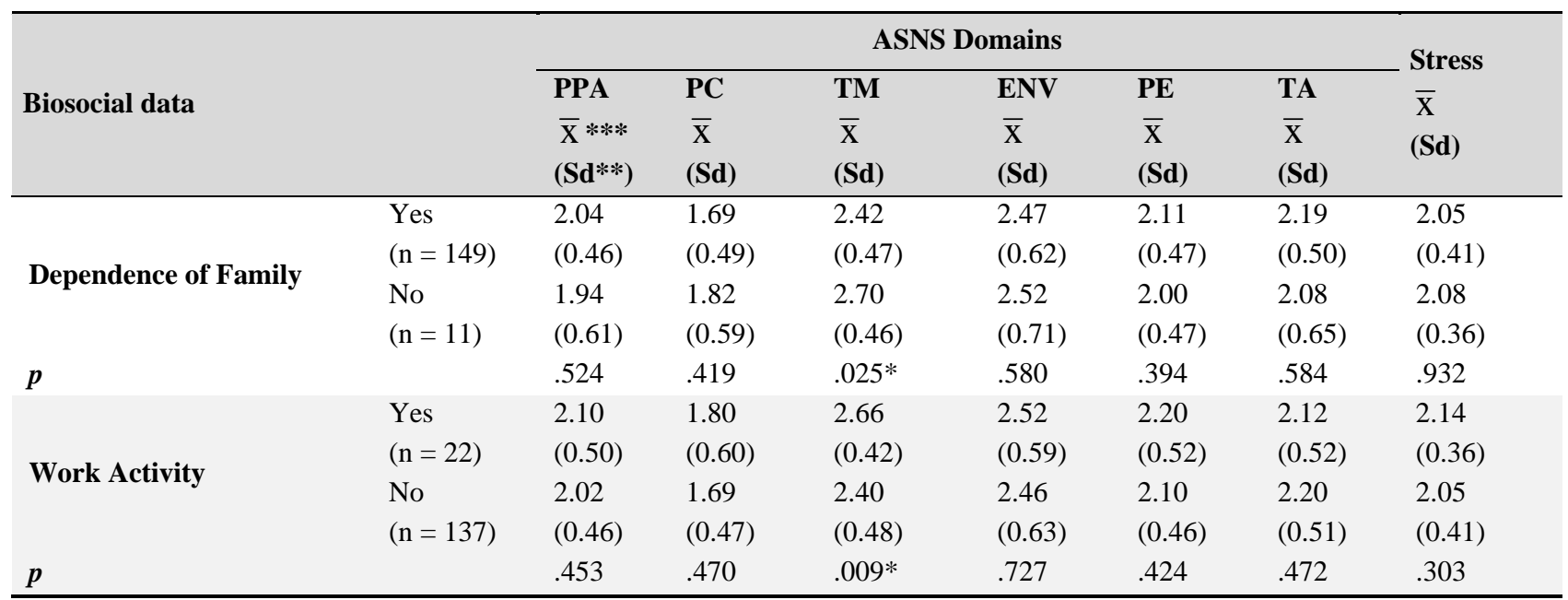

*Statistically significant difference $(p<.05)$ (Mann-Whitney Test)

$* *$ Sd $=$ Standard Deviation

$* * * \overline{\mathrm{X}}=$ Mean

\section{Discussion}

As a limitation of this research, we highlight reduced number of national and international studies that analyze stress in nursing students regarding to biosocial and academics aspects. This become the comparison between this survey results and those described by another investigations in nursing area more difficult. In as much as this profession has peculiarities experienced by and that can lead them to stress. 
Besides, the different number of cases for each category of biosocial and academic data resulted in a mean field with different proportions. It was happen because we did not used frequencies to identify what cases were prevalent, considering ASNS domains and biosocial or academic characteristics. So forthcoming studies with this design must to selected students equally concerning to each characteristic before to compare them using means or use frequencies when there is a different number of individuals in each category of biosocial or academic data.

In this sense, we observed a statistically significant difference between stress intensity in Environment domain regarding to the three means of locomotion analyzed (subway. train and car). Being that Environment represented higher stress to individuals who use subway and train to arrive at USP nursing school and (or) in place of training than those who use car for this goal. In the Environment domain, the difficulties concerning transport means used to access the different learning places are approached ${ }^{[24]}$. Thus, distance between college and home, transportation used and the distance between training places are the items present into this domain ${ }^{[24]}$.

These results may be related to context experienced by students of this research seeing that São Paulo is a city characterized as a large metropolis whose transportation infrastructure has limitations arising partly from the expansion of this city beyond the big centers. This expansion led to increasing of distances and travel time to arrival at the desired destination which may be perceived as stressful by students with repercussions to their health and well-being. This result is strengthened by assertion that traffic is a serious social problem since the 60s reflecting the industrial development of the country and linked to important socioeconomic changes and to the rural exodus with rapid, disorganized and unplanned urbanization ${ }^{[26]}$. About this, in analysis of individual perceptions of stress regarding to vehicular load and traffic, it was found that these variables are associated to lower levels of health status and to increasing the depressive symptoms ${ }^{[27]}$. The authors suggest that individuals who lives in large urban centers may be more exposed to influence of stress related to traffic with greater impact to their well-being ${ }^{[27]}$. Furthermore, in analysis of the relationship between stress and sociodemographic status in 1617 college students of Turkey, authors found that those who live in neighborhoods away from the educational institution have higher stress levels (mean $=16.33 \pm 6.28$ ) than those who live close to school (mean $=14.55$ $\pm 6.81)^{[5]}$.

There was a statistically significant difference between stress intensity in Time Management domain regarding to using the metro, and Time Management represented the most stressful domain to students who use this means of locomotion. This domain refers to difficulties reported by students to reconcile activities established in the curriculum with personal, emotional and social needs ${ }^{[24]}$. Therefore, the fact to use subway considering the time taken to arrive at home and at school reflect in how student evaluates and manages his time to develop curriculum activities which have already highlighted as stressful, and reconcile them with another daily demands. In this sense, studies show that main stressors for nursing students have been related to curriculum structure, among them, exams, competitiveness concerning assessments notes amount of content to be learned and lack of time to review what has been learned ${ }^{[15,28-30]}$.

According to authors, this demonstrates that students feel overwhelmed with the amount of information they need manage in a limited time period ${ }^{[15,30]}$. Consequently, free time for leisure and sport activities becomes compromised.

In this regard, we observed that students who do not perform leisure activities have a higher stress intensity in the Time Management, Environment and Professional Education domains as well as higher general stress intensity. Concerning sports, students who do not practice this activity have higher stress intensity in Time Management domain. About it is possible assert that not performing leisure and (or) sports activities adversely affects way in which student organizes his time to carry out academic activities; lives together with Environment situations, related to difficulties to arrive at university; and interprets aspects of their Professional Education. i.e.. The knowledge obtained in academic education and its impact on future of professional career.

In this sense, a higher stress among nursing students who do not perform physical and leisure activities is expected insofar as they improve self-esteem provide greater security to daily tasks execution and increase welfare. They also reduce risk of 
changes in students mental health, including stress and assist in social interactions important in nursing. In this way, importance of venues for leisure and sports in the academic environment is emphasized, especially for sports practices whereas 104 students do not perform them, perhaps for the need of physical structure and prior planning for its implementtation. In this sense, a survey conducted in Brazil ${ }^{[31]}$ stands out sport and leisure as elements that affect directly in the psychological (distraction. self-efficacy and social interaction) and physiological (increasing the endorphins synaptic transmission) aspects of individuals. Authors point out that this type of activity, especially when practiced in a group. favors establishment of social relations and plays a protective effect on mental health ${ }^{\text {[31] }}$. Additionally, it assists in prevention and treatment of various mental disorders such as depression and anxiety ${ }^{[29,32]}$. Therefore, according to research about leisure among ICU nurses, the necessity of deploy this type of activity in professionals performance context is stands out ${ }^{[33]}$.

We found that students who are not family dependent and have work activity showed higher stress in Time Management domain. So, it is apprehended that student who does not depend on family needs an activity that allows him to survive in a city like São Paulo whose food transportation and housing costs are considered high. Accordingly, many students work at night which may represent overhead of activities, daytime sleepiness, dysfunction in sleep-wake cycle, with repercussions for student health and academic performance. In a research with workers nursing students, authors emphasized that work of these individuals has a negative impact on sleep quality, intellectual development, quality of life and physical and mental well-being ${ }^{[34,35]}$. In this context, nursing student who work often at night are exposed to accidents injuries errors and lower academic performance ${ }^{[34,35]}$.

We observed that different variables of the biosocial and academic context, such as type of transport used, practice of sport and leisure, not dependence on family and have a job, interfere in how nursing student manages his time. In this sense, in a study with Iranian nursing students, the manner in which these individuals manage their time according to obstacles experienced in academic environment was investigated ${ }^{[36]}$. As results, we evidenced that accept unfavorable conditions and choose professional field functioned as starting point to time management and helped to deal with feelings of uncertainty and stress ${ }^{[36]}$. Besides, the students sought to devote more time for academic activities, less time to other duties and have to associate the activities they wish perform to academic duties ${ }^{[36]}$.

\section{Conclusion}

Nursing students from São Paulo live in a metropolis whose public transportation system hampers the Time Management to perform nursing school activities and reconcile them with social, personal and familiar demands. Thus, students who use subway and bus showed higher stress to manage their time. In addition, the Environment represented higher stress for students who use these means of transportation in view of barriers faced by students in path between nursing school, home and internship places.

In this context, many times, students do not find time to practice sports and leisure activities which assists in enhancing of well-being and in reduction of stress among students. Therefore, those who do not practice these activities had higher stress to manage their time, to live with Environment obstacles and to deal with academic training aspects. Thus, we propose the creation of spaces to perform these activities, especially sports, seeing that prevailed students who do not perform this activity which demands physical structure and greater planning for its implementation.

Furthermore, a few times, fact of not depending on family leads student to pursue a work activity in order to subsidize his monthly costs for food, transportation and housing. Thus, there is overload of activities, with reduction of time to sleep and rest, consequences to academic performance and health of nursing students. Perhaps because of it, the prerogative of not depend on family and have a work activity can be accounted for higher stress among nursing students in this research.

This way, the biosocial and academic context found can propitiate stress occurrence in nursing students. Hence, we suggest conduction of studies that may help students opt for more effective strategies to deal with stressors in order to they may live training period with more satisfaction and less suffering.

Published by Sciedu Press 


\section{Competing interests}

The author(s) declare that they have no competing interests.

\section{Acknowledgements and funding}

We thanks for São Paulo Research Foundation - FAPESP by financial support to this investigation.

\section{Authors' contributions}

All authors have made substantial contributions to conception and design. acquisition. analysis and interpretation of data; have been involved in drafting the manuscript and revising it critically for important intellectual content; and have given final approval of the version to be published.

\section{References}

[1] Lo R. A longitudinal study of perceived level of stress. coping and self-esteem of undergraduate nursing students: an Australian case study. J AdvNurs. 2002; 39:119-26. PMid:12100655http://dx.doi.org/10.1046/j.1365-2648.2000.02251.x

[2] Burnard P. Edwards D. Bennett K. Thaibah H. Tothova V. Baldacchino D, et al. A comparative, longitudinal study of stress in student nurses in five countries: Albania. Brunei, the Czech Republic. Malta and Wales. Nurse Educ Today. 2008; $28: 134-45$. PMid:17559986http://dx.doi.org/10.1016/j.nedt.2007.04.002

[3] Omigbodun O. Stressors and counseling needs of undergraduate nursing students in Ibadan. Nigeria. J Nurs Educ. 2004; 43:412-20. PMid:15478694

[4] Gibbons C. Dempster M. Moutroy M. Stress and eutress in nursing students. J AdvNurs. 2008; 61: 282-90. PMid:18197862http://dx.doi.org/10.1111/j.1365-2648.2007.04497.x

[5] Bayram N. Bilgel N. The prevalence and socio-demographic correlations of depression, anxiety and stress among a group of university students. Soc Psychiatry PsychiatrEpidemiol. 2008; 43: 667-72. PMid:18398558http://dx.doi.org/10.1007/s00127-008-0345-x

[6] Timmins F. Corroon AM. Byrne G. Mooney B. The challenge of contemporary nurse education programmes. Perceived stressors of nursing students: mental health and related lifestyle issues. J PsychiatrMent Health Nurs. 2011; 18:758-66. PMid:21985678http://dx.doi.org/10.1111/j.1365-2850.2011.01780.x

[7] Timmis F. Kaliszer M. Aspects of nurse education programmes that frequently cause stress to nursing students - fact-finding sample survey. Nurse Educ Today. 2002; 22: 203-11. PMid:12027601http://dx.doi.org/10.1054/nedt.2001.0698

[8] Susan L. Ellis N. The design of a stress-management programme for nursing personel. J Adv Nurs. 1990; 15 : 946-61. http://dx.doi.org/10.1111/j.1365-2648.1990.tb01951.x

[9] Admi H. Nursing student's stress during the initial clinical experience. J NursEducat. 1997; 36: 323-7. PMid:9309567

[10] Killam LA. Mossey S. Montgomery P. Timmermans KE. First year nursing students' viewpoints about compromised clinical safety. Nurse Educ Today. 2012; 32:475-80.

[11] Montgomery P. Mossey S. Killam L. Views of second year nursing students on impediments to safety in the clinical setting: Q-methodology. J NursEducPract. 2013; 3: 1-12.

[12] Moreira DP. Furegato ARF. Estresse e depressão entre alunos do últimoperíodo de doiscursos de enfermagem. Rev LatinoamEnferm. 2013; 21: 155-162.http://dx.doi.org/10.1590/S0104-11692013000700020

[13] Chou PC. Chao YMY. Yang HJ. Yeh GL. Lee TSH. Relationships between stress, coping and depressive symptoms among overseas university preparatory Chinese students: a cross-sectional study. BMC Public Health.2011; 11: 352-9.

PMid:21595974http://dx.doi.org/10.1186/1471-2458-11-352

[14] Hsiao YC. Chien LY. Wu LY. Chiang CM. Huang SY. Spiritual health, clinical practice stress, depressive tendency and health-promoting behaviours among nursing students. J AdvNurs. 2010; 66: 1612-22.

PMid:20492024http://dx.doi.org/10.1111/j.1365-2648.2010.05328.x

[15] Yusoff MSB. Rahim. AFA. Baba AA. Ismail SB. Pa MNM. Esa AR. Prevalence and associated factors of stress, anxiety and depression among prospective medical students. Asian J Psychiatry. 2013; 6: 128-33.

PMid:23466109http://dx.doi.org/10.1016/j.ajp.2012.09.012

[16] Dyrbye LN. Thomas MR. Massie FS. Power DV. Eacker A. Harper W. et al. Burnout and suicidal ideation among U.S. medical students. Ann Intern Med. 2008; 149: 334-341.PMid:18765703http://dx.doi.org/10.7326/0003-4819-149-5-200809020-00008 
[17] Dyrbye LN. Thomas MR. Huntington JL. Lawson KL. Novotny PJ. Sloan JA, et al. Personal life events and medical student burnout: a multicenter study. Acad Med. 2006; 81: 374-384.PMid:16565189http://dx.doi.org/10.1097/00001888-200604000-00010

[18] Campos JA. Jordani PC. Zucoloto ML. Bonafé FS. Maroco J. Burnout syndrome among dental students. Rev Bras Epidemiol.2012; 15: 155-165. PMid:22450501http://dx.doi.org/10.1590/S1415-790X2012000100014

[19] Costa EFO. Santos SA. Santos ATRA. Melo EV. Andrade TM. Burnout Syndrome and associated factors among medical students: a cross-sectional study. Clinics. 2012; 67: 573-579.http://dx.doi.org/10.6061/clinics/2012(06)05

[20] Bittman B. Snyder C. Bruhn K. Liebfried F. Stevens C. Westengard J. et al. Recreational music-making: an integrative group intervention for reducing burnout and improving mood states in first year associate degree nursing students; insight and economic impact. Int j nurseducscholarsh. 2004; 1: 21-26.

[21] CuthbertsonP. Lauder W. Steele R. Cleary S Bradshaw J. A comparative study of the course-related Family and financial problems of mature nursing students in Scotland and Australia. Nurse Educ Today. 2004; 24:373-81. PMid:15245860http://dx.doi.org/10.1016/j.nedt.2004.03.005

[22] Lazarus RS. Folkman S. Stress, appraisal and coping. New York. Springer. 1984.

[23] Zegans LS. Stress and the development of somatic disorders. In Handbook of stress: theoretical and clinical aspects. Goldeberg L. Breznitz S. New York. Free Press. 1986; 134-51.

[24] Costa ALS. Polak. Construction and validation of an instrument for the assessment of stress among nursing students. Rev Esc Enferm USP. 2009; 43:1017-26. http://dx.doi.org/10.1590/S0080-62342009000500005

[25] Field A. DescobrindoaEstatísticausando o SPSS. Porto Alegre. Artmed. 2009; 688.

[26] Maia RCA. Ferreira JA. Meneses RMV. Road traffic accident: an issue of lack of education in the citizenship exercise. Rev enferm UFPE on line. 2013; 7:1145-52.

[27] Gee GC. Takeuchi DT. Traffic stress, vehicular burden and well-being- A multilevel analysis. SocSci Med. $2004 ; 59: 405-14$. PMid:15110429http://dx.doi.org/10.1016/j.socscimed.2003.10.027

[28] Yamashita K. Saito M. Takao T. Stress and coping styles in Japanese nursing students. Int J NursPract. 2012; 18 : $489-96$. PMid:23009378http://dx.doi.org/10.1111/j.1440-172X.2012.02056.x

[29] Goff AM. Stressors. Academic Performance, and Learned Resourcefulness in Baccalaureate Nursing Students. Int J NursEducScholarsh. 2011; 8: 1-20. PMid:21291410http://dx.doi.org/10.2202/1548-923X.2114

[30] Yusoff MSB. 2011. Impact of summative assessment on first year medical students'mental health. International Medical Journal 2011; 18: 172-75.

[31] Rocha SV. Araújo TM. Almeida MMG. JSV Júnior. Practice of physical activity during leisure time and common mental disorders among residents of a municipality of Northeast Brazil. Rev Bras Epidemiol. 2012; 15: 871-83. PMid:23515781http://dx.doi.org/10.1590/S1415-790X2012000400017

[32] Peluso MAM. Andrade LHSG. Physical activity and mental health: the association between exercise and mood. Clinics. 2005; 60:61-70. http://dx.doi.org/10.1590/S1807-59322005000100012

[33] Pereira MER. Bueno SMV. Lazer- um caminhoparaaliviar as tensões no ambiente de trabalhoem UTI: umaconcepção da equipe de enfermagem. Rev Latino-Am Enfermagem. 1997; 5:75-83.PMid:9485871http://dx.doi.org/10.1590/S0104-11691997000400010

[34] Ferreira LRC. De Martino MMF. Padrão de sono e sonolência do trabalhadorestudante de enfermagem. Rev Esc Enferm USP. 2012; 46:1170-83. http://dx.doi.org/10.1590/S0080-62342012000500020

[35] De Martino MMF. The architecture of day sleeping and the sleep-wake cycle in nurses in their working shifts. Rev Esc Enferm USP 2009; 43: 194-99. PMid:19437872http://dx.doi.org/10.1590/S0080-62342009000100025

[36] Mirzaei T. Oskouie F. Rafii F. Nursing students' time management. reducing stress and gaining satisfaction: a grounded theory study. Nurs Health Sci. 2012; 14: 46-51. PMid:22293018http://dx.doi.org/10.1111/j.1442-2018.2011.00661.x 